\title{
The Historical Contingency of the Role of History
}

\author{
Morton J. Horwitz $\dagger$
}

I would like to discuss the ideological significance of this presentation. In his extremely brilliant paper, Professor Gordon describes legal history as essentially destabilizing and subversive, and I agree with him. Yet it is clear that legal history has not always served this function. Thus, I would like to focus briefly on the origin of the destabilizing and subversive character of legal history.

By and large, the dominant tradition in Anglo-American legal scholarship today is unhistorical. It attempts to find universal rationalizing principles. For those of you who are law students and may not be familiar with the dominant form of legal scholarship, you need only imagine your first year law school classes in order to get a quick picture of legal scholarship "writ small." The underlying structure of the law class remains that of forcing the student to reconcile contradictions that cannot be reconciled. If you do it very well, you then become a professor and you demand it of your students and you continue to do it in your legal scholarship. The ideological "tilt" of current legal scholarship derives from this attempt to suppress the real contradictions in the world, to make the existing world seem to be necessary, to be "immanent" as Professor Gordon calls it, to seem to be part of the nature of things. It is history that comes to challenge this approach by showing that the rationalizing principles of the mainstream scholars are historically contingent. Consequently, analytic scholarship is anti-historical: it regards history as subversive because it exposes the rationalizing enterprise.

Nevertheless, it is, I think, an historically contingent matter even that history should be subversive. It wasn't always this way. If you looked back and asked how people apologized for the world in 1700, you would certainly say that it was through a customary theory of law. The justification was historical: Matthew Hale's evolutionary notion of law was designed to show that existing legal institutions

† Professor of Law, Harvard University. 
and doctrines would regularly reach higher and higher forms of perfection. Blackstone incorporated Hale's Whiggish views into his own Commentaries. ${ }^{1}$ If you looked at the function of history in 1800, you would turn to Edmund Burke. Notwithstanding Burke's early reformism, his use of history was basically apologetic." Indeed, until 1900, in the Anglo-American world at least, legal history was tied to various forms of evolutionism and Social Darwinism. All of the legal history done at the Harvard Law School at the end of the nineteenth century by Langdell and Ames and others was essentially apologetic in nature. ${ }^{3}$ They tried to show that you could trace any current doctrine back to Adam and Eve through a process of natural growth.

Some time around 1900 or thereafter, the situation that Professor Gordon focuses on really did emerge. The universalizing and rationalizing tendency of the analytic tradition came to be fundamentally apologetic, and the historicist tradition turned to showing the historical contingency of the claims of the analytic tradition. If we look at the 1920s and 1930s, we find a powerful example of the use of legal history in order to delegitimate a system of thought. Progressives and legal realists used history to show the historical contingency of supposedly universal rules and doctrines. They showed, for example, that the rule of caveat emptor was not necessary and natural and that many fundamental changes in legal doctrine had occurred with the shifts from medieval to modern times or from feudalism to capitalism. ${ }^{4}$ They thus sought to undermine the claims of previous systems to universality. For the first time, I think, legal history performed an essentially destabilizing and subversive function. By 1940 or 1950, I think, this role was quite clear and dominant. So we now have two radically different styles of scholarship.

History came to be subversive at just the moment when, for reasons that are difficult and obscure, the analytic tradition committed itself to the suppression of contradiction-to the basic attempt to reconcile the irreconcilable by showing that $\mathrm{X}$ and not $\mathrm{X}$ can exist at the same time, which is essential to demonstrating that an unjust social order is capable of being rational. The interesting and difficult question, the really complicated question of historical explanation, is: Why did this particular form of rationalizing analytic scholarship come, by 1900, to represent the dominant apologetic mode of thought? Why, in turn, was history given up as a mode of apology?

1. See Gordon, Historicism in Legal Scholarship, 90 YALE L.J. 1017, 1029 (1981).

2. See id. at 1030 .

3. See id. at 1028, 1036, 1045.

4. See id. at 1034, 1042-43. 
Now, I don't know the answer and I don't have time to work it through, but I'd like to make some suggestions. The collapse of aristocratic, status-based societies after the English and French Revolutions seems to have pushed liberal thought away from custom and history, forcing it to create universal systems of thought based on the formal equality of individuals. It may be the advent of Marxism in the middle of the nineteenth century that made liberalism defend itself through unhistorical universalism. Certainly, the rise of professionalism at the end of the nineteenth century can be associated with the search for universal norms in an effort to emulate the supposed methods of the natural sciences. The one thing that does seem clear is that the situation that Professor Gordon has so brilliantly described raises basic questions concerning the political and ideological character of legal scholarship in this century. 